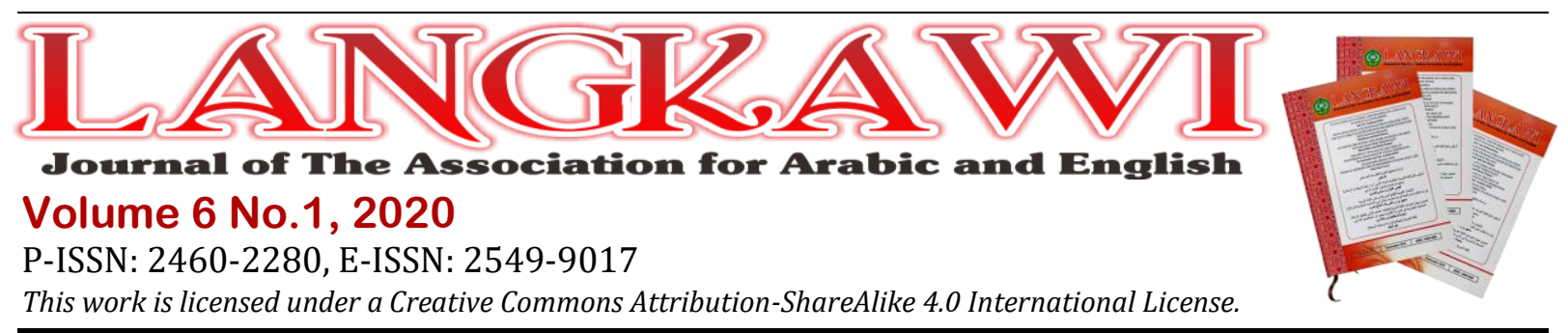

\title{
Translating Subtitles of Becoming Jane Film: A Pragmatic Approach
}

\section{Arbain}

Universitas Widya Gama Mahakam Samarinda, Indonesia. Email: baintigers@gmail.com

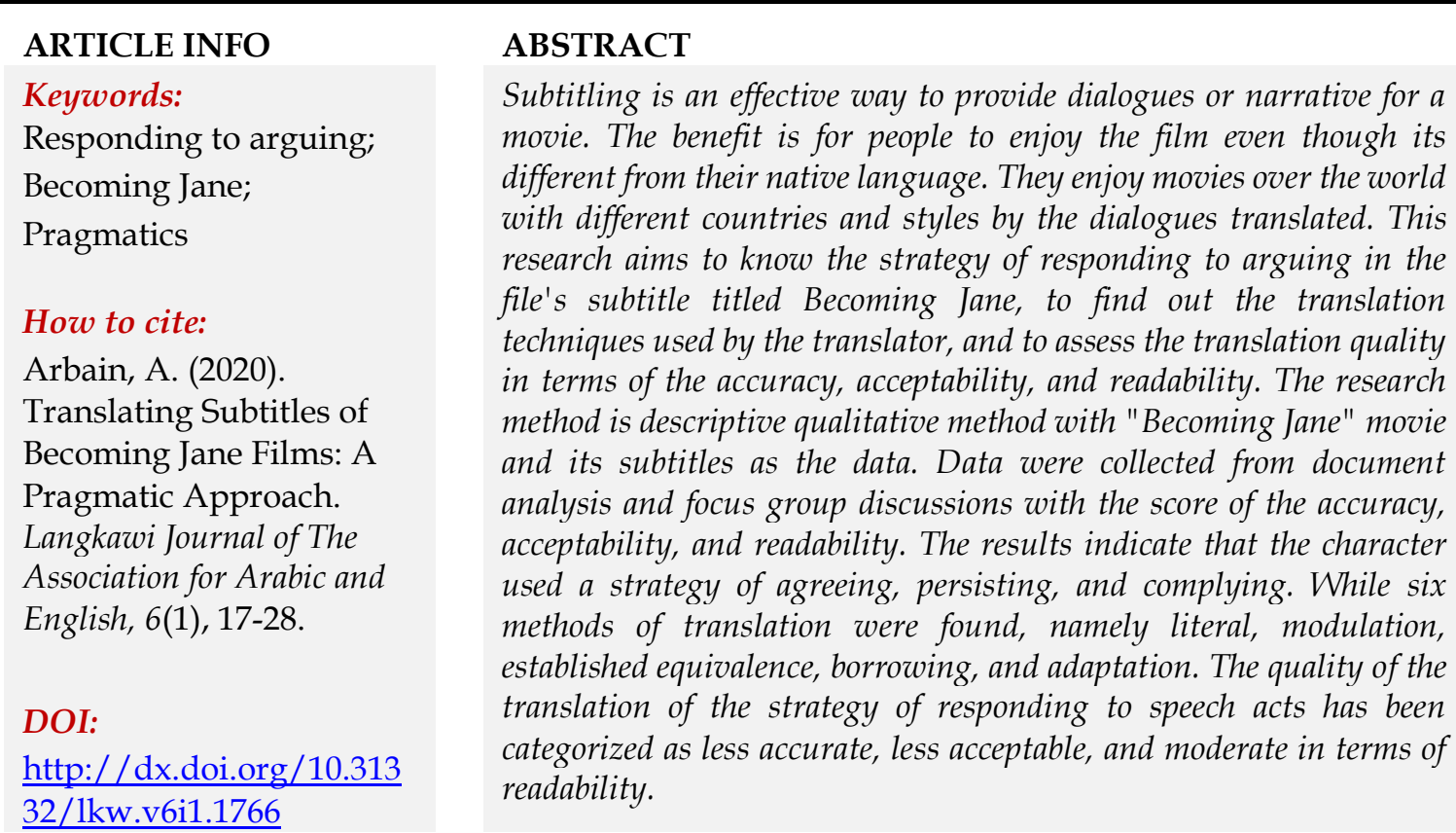

\section{Introduction}

Amid the increase of advanced technology, Indonesian films grow to achieve the quality of the translation of the subtitles in the movie. Behrens \& Parker, (2010) emphasize Films with subtitles evolve an ordinary in the entertainment business, western dubbed films are prevalent, of which subtitles translations are essential to the movie industry for the audience. Bai (2018) emphasizes that movie titles express the main idea to the audience to draw their attention. This requires the translation of movie titles to be precise and reflect the economic values. However, Bai (2018) reminds that translating a film in the language (source) to another (target) is a complicated task because of the differences in languages system, conversation and writing styles and sometimes also the gap on gender roles. It is not surprising that the translation often confuses the audience of the target language.

Consequently, it is argued that there are no standardized strategies to be an applicable guide for any kind of film translation projects (Xinya, 2016). Bai (2018) have defined characteristics of a movie title to attract the audience for two reasons. First, a beautiful title affects adding the finishing touch, appealing to the audience and giving the viewers the soul. Second, movie titles indicate the main idea of movies and attract the audience with concise and unfamiliar form. Bai (2018) suggests that the first thing viewers see about the movie is the title, so the translation of English film title is crucial. The central part of the movie can be seen from the perfect 
translation of the title that demonstrates the main thought of the movie and attracts the audience's desires.

This study explores two main concerns of investigation: techniques to which a translator finds the similar meaning in the dialogues supplied in the subtitles of a film Becoming Jane (henceforth, BJ) from English into Indonesian and the speech acts used in the talks. Drawing the translation perspectives, this study emphasizes on the translation techniques elaborating the approach of audiovisual translation. Definitely, in the exploration of the translation process, the author adapted the translation techniques of intra- and inter-lingual translations. Meanwhile, the entertained rewritings in a film subtitle are some of the academic focus (Baoxuan, 2011; Lv \& Li, 2013). Besides, the speech acts theory from Austin (1975) will be drawn in this study to analyze kinds of speech acts indicated in the dialogues.

Dries (1995) suggests that each country has a different tradition of translating films indicating one of the two primary modes: dubbing and subtitling. The decision to choose the technique is arbitrary, and factors affecting the choice vary from historical circumstances, traditions, the cost, target and the source cultures in an international context, and conventional translation techniques (Szarkowska, 2005, 2019). Theories on subtitles translation stem from Dries, (1995) from where Szarkowska, (2005, 2019) highlight dubbing and subtitling as the core models and each interfere with the original text to a different extent. Dubbing modifies the source text to a large scale. It thus makes it familiar to the target audience through domestication, which means "the foreign dialogue is adjusted to the mouth and movements of the actor in the film" (Dries, 1995:9). The aim is to make the audience feel as if they were listening to actors speaking the target language (Shuttleworth \& Cowie, 1997:45). In addition, subtitling is to translate the spoken SL dialogue into TL using synchronized captions at the bottom of the screen. It aims to enable the target audience to understand the entire contents of the films clearly (Szarkowska, 2005). Translation as communication is different from daily communication.

The spoken language applies to screenwrite. The syntax of spoken language is generally less structured than the written one. A speaker usually is more implicit than a writer. The former uses an abundance of somewhat generalized vocabulary; he often produces lots of prefabricated 'fillers' (Brown \& Yule, 2012; Yule, 1996). Besides, Dick (1990) elaborates that a standard movie advances the plot in two ways: verbally, through dialogue, and visually through action. As the visual is seen to be efficient than the verbal, the author must minimize the verbal play. The economy is an essential principle in screenwriting. Therefore, the dialogue often interrupted-that is, sentences are frequently left incomplete, and speech is just fragmentary. Thus, the language on the screen is very much like an actual conversation in daily life.

Definition of translation varies as an act to transfer from the SL into TL (Foster, 1958), the process and methods used to convey the meaning of the SL into the TL (Ghazala, 1995). This definition focuses that meaning is an essential element in translation. When translating, a translator should understand well the meaning of SL to have the appropriate equivalent in TL. Meaning is translated concerning grammar, style and sounds (Ghazala, 1995).

Catford (1965) emphasizes translation is the replacement of textual material in one language (SL) by equivalent textual content in another language (TL). It shows 
that translation is a process in the sense that translation refers to an activity. A translation is also a product, that is it provides us with other different cultures, to ancient societies and civilization life when the translated texts reach us (Hussein \& Salih, 2019).

There are strategies or techniques of translation. Adachi (2012) divides general methods of translation as liberal and literal translation, each of which has subcategories as appears in table 1.

Table 1. Kinds of translation by Adachi (2012)

\begin{tabular}{lll}
\hline Larger Categories & Smaller Categories & Definitions \\
\hline Liberal & Interpolation & a) Amplification \\
& Deletion & b) Substitution \\
& Replacement & c) Deletion \\
& & d) Adaptation \\
& & e) Description \\
& f) Discursive Creation \\
& g) Generalization \\
\hline Literal & h) Particularization \\
\hline
\end{tabular}

Kemppanen (2012) defines foreignization and domestication as translation techniques. Domesticating translation is coloured with naturalness of syntax, unambiguity, the modernity of the presentation and linguistic consistency, ethnic and ideological features, and fluent target culture that is fluent. A domesticating translation has transparency -to avoid non-idiomatic expressions, archaisms, jargon and repetition.

Foreignization is defined as a translation practice where elements foreign to the target culture are given particular stress. Likewise, a foreignizing translation has the linguistic, ethnic and ideological features of the source culture that is resistant to the norms of fluency and by unmaskedness of the translator expression (Derrida \& Venuti, 2001).

The study by Xinya, (2016), in her research, concluded that the translation theory related problems is related to cultural differences, word games, style and translation omission. Meanwhile, the linguistic issues, cultural and stylistic obstacles in the translation process are resolved by the relevant theory, by which the translator has more space to recreate his expression rather than being trapped in the "meaning and form" dilemma. The translator can render the meaning of a text into another language in the intended the text (Newmark, 2001), especially in the movie subtitle translation of the film to adjust with the unique text and the audience characteristics. It is the job of the translator to see us as possible the settings and contexts that influence speech act between characters in the film.

The author has reviewed the work of Szarkowska (2005) and the author agrees on the new perspective of a translation for a film in a global era. In the global age, the 
existence of mass communications and multimedia experiences serve audiences demand the right to share the latest text, such as film, song, or book simultaneously across cultures (Choi et al., 2017). This way, the issue of power in translation is prominent and applicable to contemporary cinema. Perceived from the pragmatic approach, translation scholars identify that translation does not take place between words but rather between cultures. The text is not conceived as a specimen of language but an integral part of the world (Yuan, 2015). As a result, the translation process involved a cross-cultural transfer, prestige the source and target cultures, and the reciprocal relations (Szarkowska, 2005).

In addition, the choice of translation is not only based on money. Szarkowska (2005) has identified that the translating strategy largely depends on the attitude of the target culture, the source culture, and political factors that determine the chosen mode. For example, Western European countries are not openly against American productions. In Arabic countries, a strong resistance exists adopting the norms and habits of the (American) adversary. In addition, the view of Indian cinematography, Bollywood, campaigns healthy anti-American attitudes.

In summary, globalization is not merely another word for Americanization; now the expansion of the Indian entertainment industry has proved it (Powell, Furlong, de Bézenac, O'Sullivan, \& Corcoran, 2019; Szarkowska, 2005, 2019). The relevant translation techniques to the globalization may vary. Specifically, Rudasingwa (2019) emphasizes that whether a translator used domesticating or foreignizing approach, any form of audiovisual translation ultimately plays a unique role in developing both national identities and national stereotypes. The transmission of cultural values in screen translation has received very little attention in the literature and remains one of the most critical areas of research in translation studies.

Drawing the pragmatic approach on the translation of BJ film, the author argues that pragmatic view the language from the procedures, process and products of translation to see the intended meaning to which cultures are involved inside and outside the text (Culpeper \& Gillings, 2019). It is to say that a film translator must have a thorough knowledge of language, culture, discourse, scientific, transfer and psychological competence of SL and TL (Bell \& Candlin, 1991).

Besides the excellency of BJ receiving great applause, recent studies on JB film using the pragmatic approach, however, is in restriction. BJ translation is considered a film that is worthy of analysis of speech acts, especially speech acts of responding to arguing. In Ireland, the BJ film has improved the economy and contributes the significant income for the country (Minister for Arts, Sport and Tourism Ireland, 2019). A study available online by Grandi (2015) has indicated that BJ is productive of ways in which speech-act theory can illuminate the worlds internal in the novel by Jane Austen. The performative speech in the BJ has been the empirical evidence that Austen's work is not only caused by language but also that language in itself is an event of an act.

This paper argues that translation of the speech acts in the film encompasses cultural differences between the SL and TL to convey responding of arguing to which the speech act theory is addressed. Arguing expresses physiological conditions to the listener or interlocutor and is categorized as an expressive speech act (Yule, 1996), it indicates the illocutionary speech acts referring as acts of doing something (John, 
Brooks, \& Schriever, 2019; Searle, 1985; Searle, 1985). Various researches regarding BJ have been done, but most of them focus on the novel and literary work analysis. This study brings an insight into translation techniques of $\mathrm{BJ}$ that concentrate on online translation techniques. The focus has not been made on the BJ before so that this current research will contribute a new academic record. In addition, to give the context of translation, this research analyzes the expressive speech acts in the dialogues that involve the translating of culture. This focus provides benefits that a combination of translating subtitle in a film based on the pragmatic approach has much relevance to the studies of translation. This study determines its purposes to see; strategies to demonstrate responding pf arguing acts by the actors of $\mathrm{BJ}$ and subheading translation techniques used in the dialogues in BJ.

\section{Methods}

This research was a descriptive qualitative approach by which content analysis was devoted (Corbin \& Strauss, 2014). As the qualitative approach, data were collected in terms of words, sentences, the logic and argumentations from where themes were the base of the analysis. It is content analysis as the research addressed recorded film of BJ to investigate the dialogues on screen. Related documents about BJ from various sources, such as journal articles, comments and critics were analyzed together with the recorded data. To analyze the data, thematic analysis was employed (Santosa, 2017; Spradley \& Observation, 1980).

The primary data of this research was a BJ corpus represented in the film record obtained from YouTube. The scene that was accompanied the dialogue texts presented in the bottom screen were transcribed. Each plot and individual dialogue in the screen were identified and recorded as the primary data. Secondary data, including a synopsis of BJ, journal articles and comments on BJ, were analyzed by the primary data.

Data, on the whole, were collected by the researcher himself as he played a crucial instrument in this research (Bogdan \& Biklen, 2007). First of all, the researcher collected initial information through the written secondary data to achieve insights on the dialogues in the BJ. Based on the initial data, the researcher came to see the film of BJ on the YouTube screen. Second, the researcher identified the text on the screen where translation from English into Indonesian was served on the bottom of the screen. The researcher recorded each dialogue then identify the translation techniques. Together with the identification, the researcher determined the kinds of speech acts of which responding actions. Third, the researcher put categories of the data based on types of speech acts and techniques of the translation used in each utterance. Finally, the researcher analyzed the data in terms of frequency that indicated how many time some data appeared, the translation techniques and speech act category. Thematic analysis by Spradley (1980) was employed to analyze the data.

\section{Findings and Discussion}

\subsection{Strategies of Responding}

Table 2 suggests that there are three strategies, namely agreeing, persisting and acquiescing, each of which has their classifications. The agreeing strategy consists of 6 types, namely, to criticize, to insult, to threat, to challenge, to compliment, and to argue. The persisting strategy expressed by the characters reveals three categories that 
are to justify, to request, and to apologize. The last strategy, the acquiescing, covers two kinds of verbal opt-out and non-verbal opt-out. The choice of a strategy to select a particular type of utterance in responding to speech acts is influenced by the closeness of the speaker and the speech partner.

Table 2. The responding of arguing strategy on the subtitle of BJ

\begin{tabular}{|c|c|c|c|}
\hline No. & \multicolumn{2}{|c|}{$\begin{array}{l}\text { Responding to Arguing Speech } \\
\text { Strategy }\end{array}$} & Total \\
\hline 1 & \multirow{6}{*}{$\begin{array}{l}\text { Agreeing } \\
\text { strategies }\end{array}$} & Criticize & 9 \\
\hline 2 & & Insult & 8 \\
\hline 3 & & Threat & 4 \\
\hline 4 & & Challenge & 4 \\
\hline 5 & & Compliment & 7 \\
\hline 6 & & Argue (take issue) & 31 \\
\hline 7 & \multirow{3}{*}{$\begin{array}{l}\text { Persisting } \\
\text { strategies }\end{array}$} & Justify & 17 \\
\hline 8 & & Request & 4 \\
\hline 9 & & Apologize & 4 \\
\hline 10 & \multirow{3}{*}{$\begin{array}{l}\text { Acquiescing } \\
\text { strategies }\end{array}$} & Acquiesce & 3 \\
\hline 11 & & Opt-out verbal & 6 \\
\hline 12 & & Opt-out non-verbal & 6 \\
\hline
\end{tabular}

To support the findings of the frequency, the following quotes are presented in scripts below.

\section{Script 1}

ST:

Mr. Lefroy: I think that you, Miss Austen, consider yourself a cut above the company.

Mr. Lefroy: You, ma'am, secretly.

Jane: "... insolent, arrogant, impudent, "insufferable, impertinent of men."

TT:

Mr Lefroy: Saya berpikir bahwa anda, Nona Austen, Menganggap diri anda melukai lawan bicara.

Jane: Saya?

Mr. Lefroy: Anda, Nona, secara rahasia.

Jane: "...besar mulut, arogan, lancang, menyebalkan, laki-laki kurang ajar.

Script 1 shows that Jane responded to the speech act by refuting by saying the deficiencies of Mr. Lefroy. Mr. Lefroy, who began the conversation hastily, said things he did not Lefroy who started the conversation, openly said something that he didn't like about Jane.

\section{Script 2}

ST:

Mr. Lefroy: Is this conduct commonplace in the natural history of Hampshire? 
Your ignorance is understandable since you lack ... What shall we call it? Jane The history? Propriety commands me to ignorance.

\section{TT:}

Mr Lefroy: Apakah ini perilaku kebiasaan dalam sejarah alam dari Hampshire? Ketidaktahuan anda dimengerti sejak anda kekurangan... Apa yang harus kita menyebutnya?

\section{Jane: Sejarah? Kesopanan memerintahkan saya untuk ketidaktahuan.}

The persisting strategy with justifying utterance type used by Jane use when responding to speech acts denied Lefroy who accused him of being arrogant and asked whether this was the habit of the Hampshire residents who in their story met face to face in the forest when Mr. Lefroy came from a lost city but Jane pretended did not see it. Jane judges herself by saying it is precise because of ignorance that makes her more polite not to say hello.

\section{Script 3}

ST:

Jane: I have read your book and disapprove.

Mr. Lefroy: Of course, you do.

TT:

Jane: Saya telah membaca buku anda dan tidak setuju.

Mr. Lefroy: Tentu saja anda lakukan.

The acquiesce strategy is found in the sample data above, wherein, in this strategy, Mr. Lefroy responded to Jane's rebuttal to his opinion of the book he shared by agreeing without the slightest rebuttal. In the data above, their closeness has turned into friends who share reading books before they finally become lovers. The proximity affects the way to respond to the rebuttal delivered.

\subsection{Sub-heading translation techniques}

This study reveals 6 translation techniques in the dialogues of BJ. The 6 techniques include: literal $95(65.1 \%)$, modulation 4 (2,74\%), established equivalence $36(24.66 \%)$, borrowing 5 (3.4\%), adaptation $6(4.12 \%)$ and deletion 1 (0.68\%). See table 3 .

Table 3. Translation techniques

\begin{tabular}{cccc}
\hline No. & Translation techniques & F & \% \\
1 & Literal & 95 & 65.1 \\
2 & Modulation & 4 & 2.74 \\
3 & Established Equivalence & 36 & 24.66 \\
4 & Borrowing & 5 & 3.4 \\
5 & Adaptation & 6 & 4.12 \\
6 & Deletion & 1 & 0.68 \\
\hline & Total & $\mathbf{1 4 6}$ & $\mathbf{1 0 0}$ \\
\hline
\end{tabular}

The table above shows the six translation techniques used by translators in the Becoming Jane subtitles, namely literal, modulation, established equivalence, borrowing, and adaptation. The literal technique is found the most in the movie subtitles of Becoming Jane. The literal technique is a technique translating per word 
from the source language to the target language. Common matching method is translation technique characterized using terms or expressions that are commonly used daily or based on a dictionary. Adaptation is a technique replacing the cultural elements of the source language with the target language. While borrowing is a borrowing technique from the source language used in the target language.

The following scripts indicate dialogues from where translation techniques are identified.

\section{Script 4}

ST:

Eliza: What do you make of Mr. Lefroy? We're honoured by his presence.

Jane: You think? He does, with his preening, prancing, Irish-cum-BondStreetairs.

Eliza: Jane!

Lefroy: Well, I call it very high, indeed, refusing to dance when there are so few gentlemen.

TT:

Eliza: Apa pendapatmu dari Mr. Lefroy?

Kami merasa terhormat oleh kehadirannya.

Jane: Kamu pikir? Dia, dengan bergayanya, berjingkrak-jingkrak, orang Irlandia di jalan Bond mengudara.

Lefroy: Yah, saya menyebutnya sangat tinggi memang, penolakan

Untuk berdansa ketika disana pria terhormat begitu sedikit.

The application of the literal technique is seen in the translation "Well, I call it very high" which is translated to "Yah, saya menyebutnya sangat tinggi memang" which causes the quality of the translation to be moderate in terms of readability. If the readability level is high, a score of 3 is obtained, if it is 2, and if it is low 1 . Likewise, the scores on the instruments of accuracy and acceptance assessment.

\section{Script 5}

\section{ST}

Judge (Lefroy's uncle); There is no money for you.

Mr. Lefroy: Surely, something could be done.

Judge: What we can put by must go to your brothers. You will have nothing unless you marry.

\section{TT}

Judge (Lefroy's uncle): Tak ada uang untukmu.

Mr. Lefroy: Tentunya ada yang bisa dilakukan.

Judge (Lefroy's uncle): Menikah adalah satu-satunya cara untukmu memiliki sesuatu.

The deletion technique is seen in Mr. Lefroy's uncle or translated as a judge because of his profession. He opposed Lefroy's marriage to Jane because Jane had nothing and said "What can we put by must go to your brothers. You will have nothing unless you marry" but in the translation do not translate the first sentence. Just translating the phrase "You will have nothing unless you marry" which translates to 
"Menikah adalah satu-satunya cara untukmu memiliki sesuatu". The technique used to translate the second sentence is a modulation technique is still with the same meaning but by changing its perspective. Deletion techniques make translation inaccurate, unacceptable, and low in terms of readability. In modulation techniques, a translator still does accurate translations; they are less acceptable and are being readable. This happens because of a shift in perspective caused by a change of the structure of sentences or words or from active to passive sentences that makes the audience accept the emphasis on different meanings from the source language.

These findings found that subtitle translation is very influential for movie lovers. As globalization allows us to exchange knowledge and culture with other countries, it impacts that in translation, customs and language styles are part of the culture (Hoed, 2006). Evidence shows that the use of three strategies of responding to express agreeing, persisting, and complying is close to the culture in digital communication. Characteristics of the modern communication are reflected well in the word choice, diction, and attitude to criticize, insult, threat, challenge, compliment, argument, justify, request, acquiesce, verbal opt-out, non-verbal opt-out each of which domestication and foreignation are closed (Crawford, 1995).

In terms of the use of the strategy in responding to speech acts denied closeness influenced it. In the case of the use of policy in responding to speech acts, it is denied that they are influenced by the proximity and responding of arguing speech acts translated with literal techniques to produce accurate, acceptable translations. Still, the readability that is being caused by the results of the translation seems stiff and does not look at the context. Likewise, the modulation translation technique gives an accurate, unacceptable, and moderate impact on legibility. This is influenced by modulation, which is a translation technique with different points of view but with the same meaning. This is also in line with the research of (Pranoto, 2018) who found modulation as a technique that causes a decrease in the quality of readability. While similar translation techniques commonly produce high accuracy, acceptability, and readability.

From the six techniques found in this study, it can be seen if the most widely used is literal techniques, then followed by the usual equivalent techniques, adaptation, borrowing, and modulation. The tendency of literal technique which shows more the quality of Becoming Jane's subtitle film translation, has accurate, less acceptable, and moderate-quality in terms of readability. This study contradicts with what have been found by some researchers (Caimi, 2006; Lv \& Li, 2015; Szarkowska, 2019) because in their research they did not see the impact of choosing subtitle translation techniques on the quality of their translations. Similarly, to translate various strategies responding to arguing, Farnia et al., (2014) discussed the act of complaining against students. Their research has not yet touched on the realm of translation.

\section{Conclusion}

This research shows that there are several strategies used by characters in the film to respond to the rebuttal. The choice of strategy is influenced by the closeness of the speaker and the power they have. It translates the strategy for responding using literal techniques, common equivalents, modulation, borrowing, and modulation. The choice of technique then impacts the quality of the resulting translation, which is 
measured using instruments developed by Nababan, Nuraeni, \& Sumardiono, (2012). The quality of the translation seen from the aspects of accuracy, acceptance, and readability in this study is not explicitly defined by confirming to the viewer's experts. The translation is evaluated based on the use of Bahasa Indonesia by the researcher and team whose native language is Bahasa Indonesia. The impact of the selection of techniques shows that common matching techniques provide accurate, acceptable and high translations in legibility. The modulation techniques impact quality that is accurate, unacceptable, and in readability. As a whole, most techniques found in BJ are literal techniques. The quality of the translation of the speech response strategy denied being categorized as less accurate, less acceptable, and moderate in terms of readability because the selection of the most widely used literal technique made the translation rigid and not contextual.

This research is expected to provide an overview of how pragmatic approaches are used in translation studies. An understanding of the responding of arguing strategies found in the subtitles of the film. The application of appropriate translation techniques conveys messages in the source-language text. The application of translation techniques determines the quality of the translation. It is expected that further research will more closely link the rules for translating subtitles with a choice of techniques which have many things than working on the translation of novels or books.

\section{References}

Adachi, R. (2012). A study of Japanese animation as translation: A descriptive analysis of Hayao Miyazaki and other anime dubbed into English. Universal-Publishers.

Al Asmari, A. (2013). Investigation of Writing Strategies, Writing Apprehension, and Writing Achievement among Saudi EFL-Major Students. International Education Studies, 6(11), 130-143.

Austin, J. L. (1975). How to do things with words (Vol. 88). Oxford university press.

Bai, Z. (2018). On Translation Strategies of English Movie Titles. Journal of Language Teaching and Research, 9(1), 119-124.

Baoxuan, Z. (2011). The intralingual and interlingual translation of film subtitles. Chinese Translators Journal, 4, 75-78.

Behrens, S. J., \& Parker, J. A. (2010). Language in the real world: An introduction to linguistics. Routledge.

Bell, R. T., \& Candlin, C. (1991). Translation and translating: Theory and practice (Vol. 298). London: Longman London.

Bogdan, R. C., \& Biklen, S. K. (2007). Research for education: An introduction to theories and methods.

Brown, G., \& Yule, G. (2012). Discourse analysis. Cambridge u.a.: Cambridge Univ. Press.

Caimi, A. (2006). Audiovisual translation and language learning: The promotion of intralingual subtitles. The Journal of Specialized Translation, 6, 85-98.

Catford, J. C. (1965). A linguistic theory of translation. London: Oxford University Press. Choi, J., Joo, M., Seong, H., Pak, K., Park, H., Park, C. W., \& Im, S. G. (2017). Flexible, Low-Power Thin-Film Transistors Made of Vapor-Phase Synthesized High-k, Ultrathin Polymer Gate Dielectrics. ACS Applied Materials \& Interfaces, 9(24), 
20808-20817.

Corbin, J., \& Strauss, A. (2014). Basics of qualitative research: Techniques and procedures for developing grounded theory. Sage publications.

Crawford, M. (1995). Talking difference: On gender and language. Sage.

Culpeper, J., \& Gillings, M. (2019). Pragmatics: Data trends. Journal of Pragmatics, 145, 4-14. https:// doi.org/https:/ / doi.org/10.1016/j.pragma.2019.01.004

Danilaviciene, G., Horbacauskiene, J., \& Kasperaviciene, R. (2017). On formulaic language in subtitling and voice-over. Translationes, 9(1), 71-82. https:// doi.org/https:/ / doi.org/10.1515/tran-2017-0004

Derrida, J., \& Venuti, L. (2001). What is a" relevant" translation? Critical Inquiry, 27(2), 174-200.

Dick, B. F. (1990). Anatomy of film. St. Martin's Press.

Dries, J. (1995). Dubbing and subtitling: Guidelines for production and distribution. Europ. Medieninst.

Farnia, M., Sattar, H. Q. A., \& Mei, H. C. (2014). Speech Act of Responding to Rudeness: A Case Study of Malaysian University Students. Advances in Language and Literary Studies, 5(2), 46-58.

Foster, M. (1958). Translation from/into Farsi and English. Retrieved April 1, 2007.

Ghazala, H. (1995). Translation as problems and solutions. Syria: Dar El-Kalem El-Arabi. Quarterly, 17(3), 121-139.

Grandi, R. (2015). Screening Jane. When History, Biography and Fiction create a Cinematic Life. Lingue e Linguaggi, 13, 301-309. https:// doi.org/10.1285/i22390359v13p301

Hoed, B. H. (2006). Penerjemahan dan kebudayaan. Pustaka Jaya.

Hussein, G. M., \& Salih, A. K. (2019). The Impact of Collaborative Learning Strategy on Novice Translators' Performance in Written Translation: A Case Study. Journal Of Al-Frahedis Arts, 1(35), 13-40.

John, P., Brooks, B., \& Schriever, U. (2019). Speech acts in professional maritime discourse: A pragmatic risk analysis of bridge team communication directives and commissives in full-mission simulation. Journal of Pragmatics, 140, 12-21. https:// doi.org/https:/ / doi.org/10.1016/j.pragma.2018.11.013

Kemppanen, H. (2012). Domestication and foreignization in translation studies (Vol. 46). Frank \& Timme GmbH.

Lv, Y., \& Li, M. (2013). On the entertainment-oriented rewriting in the subtitle translation of English movies. The Chinese Translators Journal, 34(3), 105-109.

Lv, Y., \& Li, M. (2015). On the New Features of Online Film and TV Subtitle Translation in China. International Journal of English Linguistics, 5(6), 122.

Nababan, M. R., Nuraeni, A., \& Sumardiono. (2012). Pengembangan Model Penilaian Kualitas Terjemahan. Pengembangan Model Penilaian Kualitas Terjemahan, 39-57.

Newmark, P. (2001). Approaches to translation. Shanghai: Sanghai Foreign Language Education Press.

Powell, J. L., Furlong, J., de Bézenac, C. E., O'Sullivan, N., \& Corcoran, R. (2019). The Pragmatics of Pragmatic Language and the Curse of Ambiguity: An fMRI Study. Neuroscience, 418 , 96-109. https:// doi.org/https:/ / doi.org/10.1016/j.neuroscience.2019.08.039

Pranoto, M. S. (2018). Analisis Frekuensi, Durasi dan Intensitas Suara Laki-Laki dan 
Perempuan Jawa Menggunakan Perangkat Lunak Praat, (21), 190-199.

Rudasingwa, A. (2019). Challenges and Limitations in Film translation form Kinyarwanda into English in subtitle mode. Case study of the film'Urugamba' of Mwizerwa J. Hervé. University of Rwanda.

Santosa, R. (2017). Metode penelitian kualitatif kebahasaan. Surakarta: UNS press.

Searle, J. R. (1985). Expression and meaning: Studies in the theory of speech acts. Cambridge University Press.

Shuttleworth, M., \& Cowie, M. (1997). Dictionary of translation studies. Manchester: St. Jerome Publishing, 192, 193.

Spradley, J., \& Observation, P. P. (1980). Holt. Rinehart \& Winston, New York.

Szarkowska, A. (2005). What is relevant in audiovisual translation? Relevance Studies in Poland, 2, 233-245.

Szarkowska, A. (2019). A project-based approach to subtitler training. Linguistica Antverpiensia, New Series-Themes in Translation Studies, 18.

Xinya, L. (2016). Movie subtitle translation: Relevence theory perspective with reference to the movie the shawshank redemption as the case study. International Journal of Language and Linguistics, 4(2), 61-69.

Yuan, L. (2015). The subtitling of sexual taboo from English to Chinese.

Yule, G. (1996). Pragmatics: Oxford University Press. Oxford. 